\title{
Assemblages of care and the analysis of public policies on homelessness in Turin, Italy
}

\author{
Michele Lancione
}

\begin{abstract}
The paper investigates the ways urban policies on homelessness are discursively framed and practically enacted in Turin, Italy. The notion of 'assemblages of care' is introduced to show how these policies contribute to the constitution of different experiences of homelessness, by mean of their discursive blueprints and practical enactments. Relying on a tenmonth ethnographic fieldwork, the paper questions four particular policies that present two main patterns. Three of these interventions, without being able to take into consideration the specificity of each subject, present relevant negative consequences on homeless people's emotions and ways of life. The remaining policy, which relies on a different approach to homelessness than the one previously outlined, seems able to produce alternative assemblages and more positive engagement with the individuals encountered. The conclusion provides critical reflections able to inform practices that extend beyond the analysed case.
\end{abstract}

\section{Keywords}

Assemblages of Care; Power; Homeless people; Homelessness' policies; Urban Ethnography; Turin

\section{Short bio}

Michele Lancione is Post-Doctoral Fellow at the Department of Geography, University of Cambridge, UK. Email: michele.lancione@geog.cam.ac.uk 


\title{
Assemblages of care and the analysis of public policies on homelessness in Turin, Italy
}

\author{
Michele Lancione \\ 'How sweet the air does smell - even the air of a back-street in the suburbs - after \\ the shut-in, subfaecal stench of the spike!'i
} (George Orwell, Down and Out in Paris and London, 1933)

\section{Introduction}

Public and private institutions always play a role in the affecting of one's own life. They set rules, codes, normative behaviours and patters that we, consciously and unconsciously, follow and challenge. This is true not only when the power of the institution takes the form of physical containment (Basaglia 1964; Foucault 1991; Goffman 1961), but also - as in the case here - when this power is diluted into everyday practices of care (Darling 2011a). These practices of 'care', where the latter term is more broadly understood as 'the proactive interest of one person in the well-being of another and as the articulation of that interest (or affective stance) in practical ways' (Conradson 2003a, 508), do indeed have effects that are not obvious at first sight (Mol 2008; Green and Lawson 2011). Scholars have investigated the constitution of ambiguous spaces of care in the provision of services for homeless people (Johnsen, Cloke, and May 2005a; 2005b), people with mental health problems (Parr 2000), refugees (Darling 2011b), and other populations (Fyfe and Milligan 2003). On the one hand these spaces provide important material, and sometimes spiritual help to the ones in need, and they also compensate (especially in the case of Faith-Based 
Organizations, FBOs) for the withdrawal of the public sector from the arena of social policy (Romanillos, Beaumont, and Şen 2013; Staeheli and Brown 2003). On the other hand they contribute to the normative characterisation and sometime stigmatization of their recipients (Parr and Philo 1995), as well as affecting them through emotionally painful encounters (Lancione 2014; Liebow 1993).

The paper ethnographically investigates the policies of care for homeless people delivered by the City of Turin, Italy, thus contributing to the literature concerned with similar interventions and their relative spaces (Conradson 2003b; Milligan et al. 2007). It does so by following the most recent developments in homelessness scholarship, which departs from the canonical evaluation of public policies as 'punitive' (Davis 1992), 'annihilating' (Mitchell 1997; Mitchell and Heynen 2009), or 'revanchist' (Smith 1996; 1998) forms of control toward homeless people (for a critique of these approaches see DeVerteuil, May, and von Mahs 2009; DeVerteuil 2006). The new 'performative' scholarship proposes instead to understand homelessness 'from within', positing a specific attention on homeless people's 'performativities [that are] bound up in complex ways with the architecture of the city' (Cloke, May, and Johnsen 2010, 62; 2008). In proposing detailed accounts of homeless people own' experiences, this scholarship is then able to provide nuanced narratives of life on the street that may inform the subtle effects of policy making (DeVerteuil 2003; May 2000).

Building upon this scholarship and on related publications (Lancione 2013a; 2013b), the paper confronts its case study through two interdependent perspectives.ii First, it denies overarching metanarrative: the institution is not neoliberal a-priori, it does not necessarily harass homeless people and, even in the case of it doing so, the aim is to understand how the harassment come into being more than stating - or shouting - that we are confronted with an harassment (on the apocalyptical language of the 'punitive approach', see DeVerteuil 2012). Second, it proposes to evaluate these policies paying 
attention to the 'emergence and process' and at the 'multiple temporalities and possibilities' (McFarlane 2011a, 206) that arise in the way they assemble with their recipients. The paper offers, in this sense, an exploratory engagement with the process of assemblage that takes place between policies, the spaces that they enact, and homeless people (Farías 2011; on assemblages and policy making see McCann 2011). In order to provide a critical evaluation of this process the paper focus on the power that is relationally translated by these interventions (Ruddick 2012; Allen 2011): both in the ways they target homeless people and how they are practically put in place. In the first case we can recognise a discursive form of power: policies create a 'discourse of homelessness', which in the end serve to sustain their scope of action (Gowan 2010; Takahashi 1996). In the second, we see a practicebased form of power. Care is performed through volunteering, social assistance, provision of beds, blankets, waiting rooms, schedules, IDs, etc. These are actants having pivotal agencies both in shaping how the service is delivered (Johnsen, Cloke, and May 2005b), and in characterising its particular affective atmospheres (Anderson 2009; 2012).

The approach proposed in this work consists, then, of the thick ethnographical description of public policies as assemblages of care which are made up, as any assemblage, by their discursive 'expression' and practical 'content' (Deleuze and Guattari 1987; Dewsbury 2011) iii and in their critical analysis from the contextual and heterogeneous responses they provoke from homeless people (McFarlane 2011b). Through this analysis one does not intend to reject the relevance of the work that the City of Turin does concerning homelessness, but to take fully into consideration the relational power expressed by it. What follows is an investigations of policies that, for the most part, should not be dismissed but implemented in a different way: taking into consideration the non-obvious diagrammatic effects (Huxley 2007), sometimes positive and sometimes not, which they procure to their 
recipients (on assemblages and diagrams see Deleuze 1988; De Landa 2000; also Legg 2011).

The paper is organised as follows. Section two introduces the ethnographic case study. Section three presents the main approach on homelessness promoted by the City of Turin through the analysis of three representative policies. Section four thus presents one other policy adopted by the City, which relies on a slightly different approach than the one previously outlined and provides different outcomes. The conclusion re-reads these accounts providing reflections to inform both the analysed practices and other similar cases.

\section{The case-study: Turin and the 'Servizio Adulti in Difficoltà'}

The paper relies on materials collected in an intensive ten-month ethnographic fieldwork that I conducted from September 2009 to June 2010 in Turin, Italy. The fieldwork involved extensive observations with homeless individuals on the streets (at least 4 times a week), participant observations (and volunteering) in a soup kitchen and a shelter ( 4 times a week), observations undertaken while frequenting a multifunctional centre and shelter, owned by the City and managed by a group of social workers called 'Educativa Territoriale' (on which I will return later), as well as in-depth interviews with homeless people (43; plus a set of longitudinal interviews with selected individuals), practitioners (16), and a collection of secondary data (Lancione 2011a). Since homeless people mostly felt uncomfortable with the practice of audio-recording interviews, to collect data I relied on a mixture of intensive in-field note-taking, post-field notes, and photos representing the investigated contexts. The verbatim presented in this work comes, however, from taped interviews.

To begin with, it is worth noting that Italy does not provide a clear and well defined national policy or strategy, on homelessness. Cities, as 
also seen in other European contexts (Filipovi, Somogyi, and Teller 2009), are almost left alone to manage the matter. Turin is no exception. Besides the important role played by FBOs (Lancione 2014), the most relevant services are managed by a public body called 'Servizio Adulti in Difficoltà' (SAD - Service for Adults in Need). The access to the SAD's services is not automatic and is related to the residential status of the recipient, which usually takes two forms: people deprived of any identity document (ID) and hence of any formal residence, and people in possession of documents testifying to their residential status in another municipality other than Turin.iv In these cases the SAD offers two possible routes.

In the first, individuals are encouraged to apply for a 'fictive residence' in the so-called 'Via della Casa Comunale, 1'. This is a fictive route created for administrative purposes: by obtaining an ID that shows their residential status in this fictive street, homeless people formally declare their homeless status, thus becoming fully eligible for the resources offered by the SAD (Città di Torino 2009a). These include access to all the first-aid public shelters of the city, on a basis of 30 consecutive and renewable days; the possibility of attending a personalized colloquium and receive assistance in order to get financial aid from the City; assistance for the procedures necessary to get social housing; the possibility of following one of the reintegration paths proposed by the SAD, which include smaller first and second-level residential dormitories (where the individual is monitored by social educators); and specialized sanitary assistance. The second route is for the ones that do not apply for the fictive residence, and are therefore deprived of any of ID recognised by the City. Individuals are allowed to take advantage of a few services, but only in accordance with specific, limited, modalities: access to dormitories is granted only for 7 consecutive nights (which are renewable only according to availability); and medical assistance is provided for free only by the multifunctional services located near the main train station. For this second group of people it is then impossible to access the second level services and 
dormitories; to apply for any financial help or social housing; and to be formally helped and monitored by a social worker (they could do so only taking the first route: obtaining a fictive residence in 'Via della Casa Comunale, $1^{\prime}$ ).

I will evaluate SAD's policies against the steps previously outlined: first, by showing their expression (discursive rationale) and content (practical enacting); and second, by paying attention to how homeless people experience the interaction with them. Following this approach I have been able to identify three cases in which the policies of the City were negatively affecting homeless people, and one in which a different kind of assemblage was put forward.

\section{Normative assemblages}

An interview with the Social Services' Municipal Councillor of Turin (the highest ranking political figure in the City in this field) offers a starting point to retrieve the discursive rationale underlying most of the City's interventions. Asked to whom the services that the City offers were directed, he answered:

'The target audience is represented by people without economical and personal resources, to which we should add relational fragility and social marginality. Often there is the coexistence of problems that are competency of the health system, such as addictions and/or mental disease/distress, or even problems relating to the competency of the Ministry of Justice. The variety of the problematic means that there is the necessity to offer integrated answers to complex needs, in particular to the ones of health' (italics added) (M.B., Jun. 2010).

This picture of homeless people is centred on two particular discourses: the personal deficiencies of the individual, and their health issues. The first are represented by those elements that push the individual away from the stereotype of the productive occidental man - with a job, a wide and strong social network, and certain codified personal abilities (Takahashi 1996). The second is a discourse that tends to associate 
certain pathologies with the condition of homelessness, without questioning if these are a default characteristic of a homeless person or if they are successive emerging features of their relational life on the street (Gowan 2010). The SAD put similar discourses forward:

'[The SAD] takes care of homeless people, some of whom hold a fictive residence, 'Via [della Casa] Comunale'. [...] The problem expressed by the users is related to the lack of a house and a job, but behind it are hidden personal difficulties and suffering. There are many alcoholics with health issues, addicts and psychiatric patients. Our operators, as well as the one in the shelters, escort these people to the therapeutic facilities [of the city]' (A.G., head of the SAD at the time. Quoted in Fallico 2011; emphasis added)

Available documentation produced by the SAD plays along similar lines (Città di Torino 2009b). The issue is not related to what this discourse does say - it is indeed undeniable that health and mental problems, as well as the addiction to substances, are part of the homelessness matter. Rather, the issue is related to what this discourse does not say, and to the implications of framing homelessness in this way. The homeless person that emerges from these discursive frames is recognised and depicted more for what s/he lacks (economical and personal resources) than for what s/he has (or could have); more for her/his health problems (addictions and metal diseases) than for her/his potentialities. Moreover, a strong stress is put on the health issues of the individual, which is typical of a 'disease' model-approach to homelessness criticised by many scholars (Barnao 2004; Gowan 2000).

This particular way of discursively framing homelessness - as a matter of lacking something - is the (mainly unconscious) blueprint for the kind of normative practices that the City put in place. 'Normative', in this case, stands for the fact that these practices of care do not challenge the main discourse, but reinforce it by means of assembling with it. As the following cases show, the assemblage takes place through policies largely inattentive to the specificities, and necessities, 
of each subject. The assemblages of care in Turin are not, in other words, designed (or diagrammed) from an understanding of the heterogeneity of homelessness (which includes wishes, desires, personal expectations, capabilities, etc.); but from the canonical and pathological discourses framing it (Canguilhem 1989).

\section{The ' $1+1$ '}

The first case is related to the so-called ' $1+1$ ' system. As previously noted, if someone did not have a residence in Turin (either real or fictive) they were entitled to a bed in a public dormitory for no more than seven days. Afterwards, they were placed on a waiting list for a new dormitory and, while they waited, often for several weeks, they had three options: to sleep on the street (or in trains, or in other liminal spaces); to sleep at the "Emergenza Freddo"s camp, but only during the winter ('Cold Emergency', see below); or to try the so called ' $1+1$ ', a day-by-day venture to get one of the two non-bookable places that every dormitory allocated per night.

Silvanov was a homeless person I met at the beginning of my fieldwork. His description of the ' $1+1$ ' system is very emblematic (and was shared by all the homeless persons that I encountered). The first thing to notice is the emotional frustration of having to deal with such a system:

'You have to stand in front of the dormitory at 4, 5 p.m., and start queuing. You stay there, and wait. You can't go later on... you won't find any bed. The place is full of people that just stand in front of the dormitory all day long. There are even people that take the place for someone else... and then you have to fight. It's insane' (Silvano, Oct. 2009).

Then, there is the waste of time that such a system implies, a waste that influences the ways homeless people spend their days:

'If you go there at 4 p.m.... you know what this means? That you can't do anything else. You wake up, you go to the nuns [at a soup kitchen managed by the Vincenziani's community] then you hang around a bit and it's time for 
lunch. When you start to look for a job, it's already time to queue at the dormitory: what kind of life is this? Tell me. How am I supposed to deal with this? To get out of here?' (Silvano, Oct. 2009).

In the end, there is the stress of sleeping one night in one place without knowing what is going to happen the following night:

'When you go out in the morning you know that you have to start all over again, from the beginning. I can't leave my stuff anywhere. I can't settle. I've nothing with me, I can't think of anything else but where I'm gonna queue that afternoon. I can't go on like this. I've to get away, to find another way' (Silvano, Oct. 2009).

Dealing with the ' $1+1$ ' affected homeless people emotionally on a daily basis: from feelings of success (having secured a place) to failure (the contrary). Moreover, the ' $1+1$ ' forced them to physically move around the city, continuously changing dormitory. Besides the obvious physical distress of this venture (Figure 1), one should not forget the emotional freight associated with such movements, not least because the spaces of the dormitories 'have moods and physiologies as much as people did' (Desjarlais 1997, 58). Homeless people doing the ' $1+1$ ' were negotiating everyday new relational patterns, receiving contradictory and multiple stimuli, which in the end reduced the possibility of alternative endeavours (Snow and Anderson 1993).

In getting closer to the assemblages forming the ' $1+1$ ' one could better appreciate the implication of this policy on its recipients. Some of the people I encountered were purposively refusing to engage with this system because they perceived it as denigrating. Ivano was one of them:

'No way am I going to queue there. You see? Everybody sees you. And you have to wait for so long [...] I go to the Martini instead [one of the major public Turin hospitals]. I go there at $9.30 \mathrm{pm}$. I go in the waiting room. They don't ask you anything. You just sit. And they got RTL 102.5 playing [a popular Italian Radio].[...] I sleep on the chair... Wine helps. But the chairs are hard!' (Ivano, Feb. 2010). 
Central to Ivano's account of the ' $1+1$ ' system is the queue, the assemblage where this policy took its most evident material form. The queue is an assemblage with a particular aesthetic, which is immediately understood by those passing by it and looking at it. Five to ten homeless individuals, drinking and smoking, sitting on a pavement or on the stairs leading to a dormitory signify only one thing: poverty. Their arrangement/assemblage, perpetuated everyday in time and space, represented like a mirror what 'we' canonically expect to see: deprived individuals waiting for help. The ' $1+1$ ' was then not only a queue, but a normative spectacle broadcast everyday on the street. The power expressed by it took at least three forms: a) it reproduced a particular kind of aesthetic, which had an effect on how people perceived themselves (Goffman 1990); b) it moved the subjects assembled within it, by mean of stress, tensions, and fights, producing a particularly unpleasant affective atmosphere; c) it moved subjects away from it, as showed by Ivano avoiding the queue and preferring a chair instead of a bed, in order to dissociate himself from something that did not represent him.

The relational powers enacted by the queue (of self-deprecation, stress, and avoidance) were not intentionally designed in the ' $1+1$ ' policy. They were contingent and contextual effects brought about by the arrangements at play in the enactment of that policy: by particular discursive framings on homelessness and poverty ('the poor will wait under any condition, because s/he is lacking something s/he desperately needs'); by the location of the queue (on the pavement); by the proximity of bodies; by cigarettes, alcohol, and smells; by ten names on a list from which only two will be selected; by the joy and fear, tensions and relief, brought forward by the act of waiting; and so on.

Figure 1 
Homeless person resting in the premises of the Vincenziani's soup kitchen

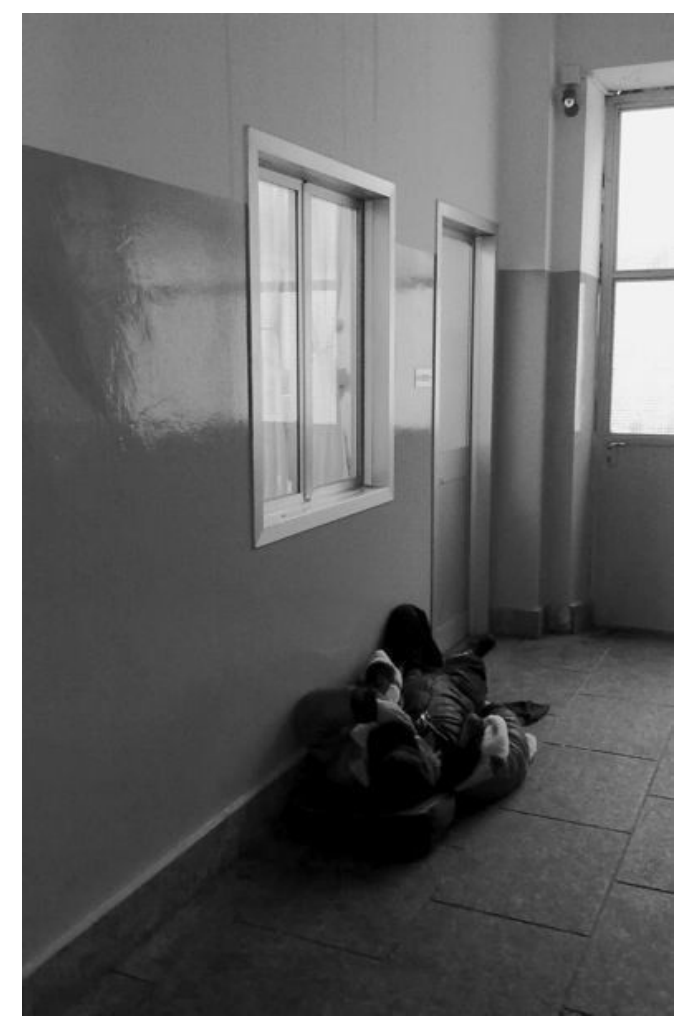

'When you miss the $1+1$ you won't sleep. So what do you do? You try to survive until the morning. And then you sleep wherever you can' (Silvano, Oct. 2009)

(Source: Lancione, 2010)

\section{Via della Casa Comunale, 1}

The second example concerns the bureaucracy that surrounds the obtaining of the fictive residence in 'Via della Casa Comunale, 1'. As it has been previously noted, in many cases this residence was the only way to avoid the ' $1+1$ ' system, and although the majority of homeless people did not like it because of the stigma attached to it, some others chose it anyway. To gain access, individuals needed to demonstrate to the SAD two fundamental things: that they did not reside anywhere and that they had no possessions. If the first point was quite easy to demonstrate by everyone, the second posed some issues.

Daniele was a homeless individual without any documents, as he had lost them and was unable to get another copy from his original town of residence (a condition common among many other homeless people 
that I encountered). Although he was not enthusiastic about the idea of getting a fictive residence in 'Via della Casa Comunale, 1' he decided to get it anyway. However, although no longer in possession of it, Daniele was still formally the owner of a car. For this reason the procedure to obtain the ID was taking more time than it should have:

'I got this car... I can't even remember when. [Pause]. I don't have it anymore, of course! But their fucking PC still says that I'm the owner. But owner of what?! I don't have that car anymore' (Daniele, Apr. 2010).

The only solution for him was to cancel ownership of the car, but this would have cost about 80 euros and implied yet further paperwork. The SAD could not provide this money to him, as he was not entitled to receive any help from the city:

'How can I pay for this? I'm stuck. They do not pay for me. I don't have the money. I can't get the residence. And that's it. I do not understand this system. [Pause]. The best thing would be to go there [to the SAD offices] and say: fuck you all! Then to run away' (Daniele, Apr. 2010).

The bureaucracy necessary to obtain the fictive residence in 'Via della Casa Comunale, 1' could be viewed as a kind of 'governmentality', as a way 'to arrange things in such a way that, through a certain number of means, such-and-such ends may be achieved' (Foucault 2000, 211), where the 'certain number of means' were the two conditions necessary to get the card (which is the end to achieve). This diagrammatic form of governmentality had particular effects on the individuals that related to it. Daniele was stressed, incredibly angry toward the 'system', and could not understand why things could not be easier for someone in his position. When speaking about this matter he would tell me: 'They do not want to help you, they want to drive you crazy!' (Daniele, Apr. 2010). He was losing faith in the system of care provided by the city, and every-time he met with someone from the SAD, or tried to obtain information from other the city's offices, he was returning depressed and demotivated (Figure 2). 
Encountering the governmentality of 'Via della Casa Comunale, 1', individuals became increasingly frustrated due to the difficulties in understanding the process. Moreover, when the residence was finally gained, there was a further stigmatizing effect difficult - if not impossible - to overcome. Giuseppe - another long-term homeless individual and part of my study - was claiming that to have written in his ID that he was residing at 'Via della Casa Comunale, 1' was like wearing a signal advertising he was a homeless person. In this sense, Giuseppe's account is similar to the one portrayed by Liebow, when he reported the story of a woman arguing that it was impossible for her to find a job because the only telephone number she could give to her possible employer was the shelter in which she was sleeping:

'To give the shelter telephone number as one's own is, in effect, to announce that one is homeless, staff at the day shelter answer the phone with 'Mainlie Church Day Shelter for Women'. Shirley protested that she could never get a job as long as shelter staff answered the phone that way' (Liebow 1993, 53).

In the end, the 'Via della Casa Comunale, 1' policy was proposing to the individual a standardized and monolithic procedure without being able to take into account one's own specific matters (as with Daniele's old car issue, or Giuseppe's wish to work), thus embroiling the subject into a powerful, highly binding and conditioning, assemblagebureaucracy.

\section{Figure 2}

Two young homeless individuals waiting to be served at one of the city's offices 


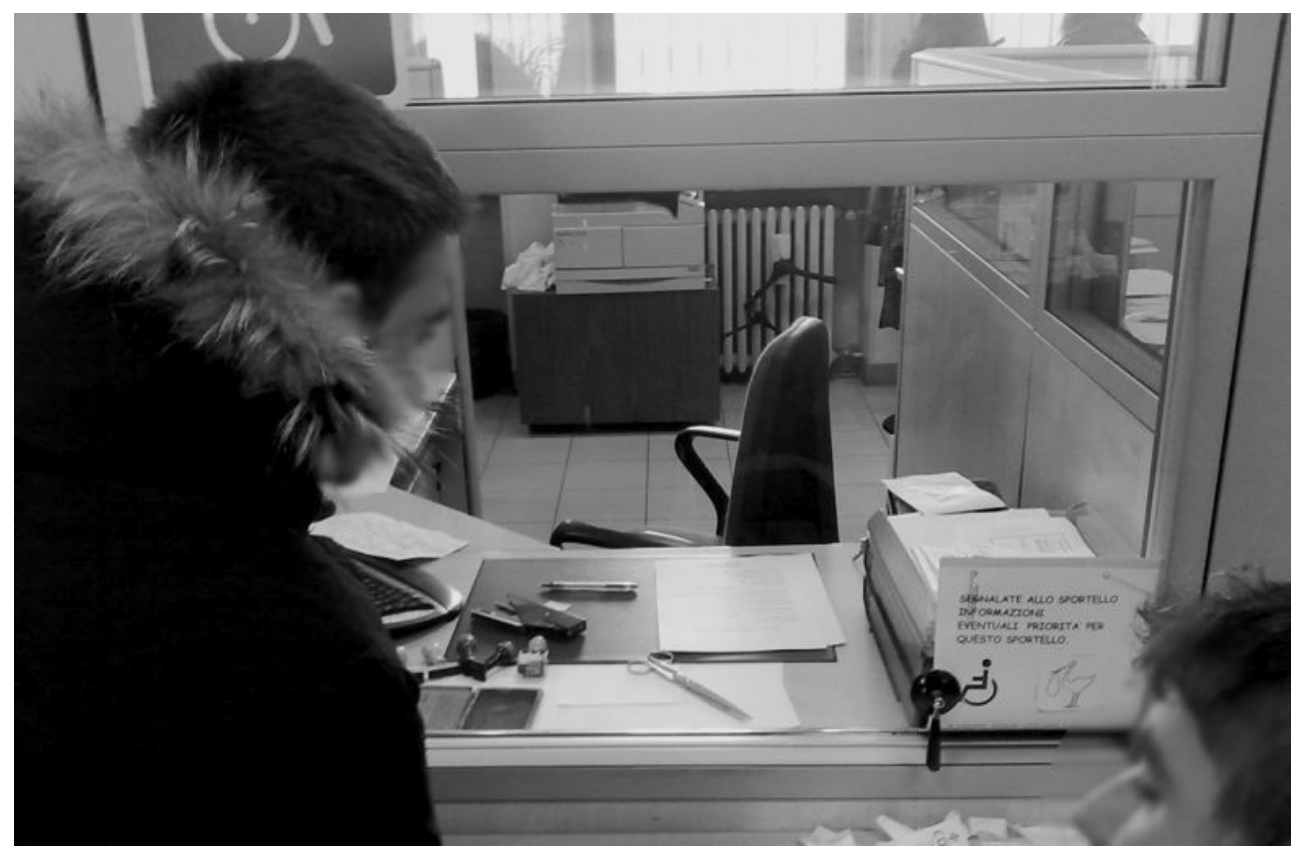

(Source: Lancione, 2010)

\section{The 'Emergenza Freddo' camp}

The third case regards a place where homeless people who couldn't sleep in dormitories or on the street, could go during the winter season: the 'Emergenza Freddo' camp (Figure 3). The 'Emergenza Freddo' was located in the middle of one of the biggest public parks in Turin, on the far west side of the city. The project started in 2003, and was 'finalized at hosting homeless people during night' in the cold season (it was usually open from November to late March) (Città di Torino 2009c). The camp was made up of 15 containers, which could accommodate up to 8 people each in bunk beds. It was open from 7.30 p.m. to 8.00 a.m. every night, and offered, apart from a place to sleep, a shared bathroom, two showers and free coffee both in the evening and in the morning. Two people, one from the Military Civil Protection and another from the Red Cross, monitored the entrance of the camp, and slept in a separate container located near the others.

Homeless people entered the camp without any documents, and slept there as long as there were free beds. Although formally forbidden, the consumption of alcohol and smoking was a common practice in the 
units and violent verbal and physical fights were the norm. For this reason the assistants of the camp were calling the police almost every night. It was therefore possible to get into the Ermergenza Freddo's camp without documents and then have free reign. In this sense, this place could be seen as 'exceptional' from the others shelters of the city, where control was much tighter and the codes of conduct were strictly implemented. In the Red Cross' Vademecum for the activities of the camp was written:

'Service staff must register the guests asking them their generalities: Name Surname - Nationality - Sex (it is not necessary to ask for any Identity Document, as this area [the Camp] is recognized as 'free zone' unlike all the other dormitories of the city)' (Croce Rossa Italiana 2008).

In this sense, if 'being outside and yet belonging: [...] is the topological structure of the state of exception' (Agamben 2005, 35), the Emergenza Freddo's camp was a state of exception outside of the city's normal rules, but run by the city itself and established within it through the suspension of the norm. In the call for the public financing of the camp it is possible to ascertain the reasons why such an exceptional space was created:

'The project has among its objectives the assurance of a service that protects the physical integrity of vulnerable subjects, and to protect the general interest of the whole community under the profile of security, health, public order and of civilized living' (Città di Torino, 2009c; italics added).

Moreover, in an interview that I conducted with the head of the camp, he told me:

'Listen to me. This is a thing that has been done to remove dangerous people from the streets. The Mayor does not want them on the street. They create problems, especially when they are drunk. Here, instead, they are left to their own destinies without annoying anyone' (A.P., Feb. 2010).

The discourse that emerges from these comments is one that aims at creating an exception (the camp) for two reasons: to offer a warm place during winter in order to 'protect the physical integrity of vulnerable subjects', and to control a population perceived as 
dangerous and deviant. Both discourses are evidentially related to the main normative framework underlying this and the other analysed policies. However, the exception was not only responding to the two needs for which it was created, but was creating other, much more relevant, effects on homeless people's subjectivities. The camp-aspolicy, if understood as an on-going set of assemblages, reveals its true power.

The aesthetic and materiality of the camp - expressed by the containers - and its geographical location - on the edge of the city were powerful characteristics of this assemblage. Marco, a young homeless individual, was shocked by his first encounter with the 'Emergenza Freddo'. When he first arrived there, he felt that he was entering 'the bottom of society' (Marco, Jan. 2010): he couldn't stand the long queue to get in, or the forty-five minutes by bus to get there, or the idea of sleeping so closely to complete strangers; he was terrified by the tiny space that was allocated to him; and he felt humiliated by the free coffee in a plastic glass offered every morning by a Red Cross volunteer. Moreover, the dark and cold containers where homeless people like Marco were sleeping were tacitly speaking to the rest of the city, as much as the ' $1+1$ ' queue or the fictive ID was doing. These containers, originally designed for the transportation of goods, were now removing unwanted bodies from the streets of Turin offering them a bed, but at a particularly high price.

This emotional price becomes evident if we look closely at the exceptional nature of the assemblage-'Emergenza Freddo'. The following accounts by Roberto - a long-term homeless individual - are illuminating in this sense:

'At the Pellerina's [the Park where the Camp was situated] people do whatever they want. They drink, they fight, they masturbate, and they shit, everything: no rules. The Red Cross man shuts himself in his container and that's all people can do whatever they want. And if you are there the choices are just three: you drink and you try to pass the night, you fight with someone, or you 
are lucky that you are so tired that you fall asleep. [Pause] But it does not last long. Someone or something always wakes you up!' (Roberto, Dec. 2009).

The exceptionality of this place subjected these people to a whole set of encounters that are unusual at night - noises, smoking and drinking, shouting, and fighting:

'You can't sleep there! You've to trust me. Would you sleep if someone is smoking, someone else snoring like a pig, and in the other container a fight has just broken out? Would you tell the one who is smoking and talking with his friend to stop doing so? They are crazy. It is full of Moroccans and Rumanians there. They always have knives with them. I go there just 'cause it's warm, that's it. But I'm gonna stop with it, it's shit' (Roberto, Dec. 2009).

The assemblage-'Emergenza Freddo' was therefore characterised by a tremendously uncomfortable and stressful affective encounter. If the first part of the project's document states that its aim was to protect the 'physical integrity of vulnerable subjects', the suspension of the norm at best did not allow for this protection. Homeless people like Roberto were thus deeply demoralised because of spending the night there. Alcohol was their companion, increasing dependency and risks to their health. A sense of defeat pervaded them, because they already knew before going into the Camp that inside it was barely possible to sleep without being awoken by some fight or other issues. The strong aversion of homeless people for this place was demonstrated by the fact that the camp never reached its full capacity and that many of them preferred to sleep in trains or on the street rather than going into those containers.

What emerges from this analysis is that the constitution of an exception like the "Emergenza Freddo"s camp had consequences that cannot be simply understood from its aims, and cannot be simply limited to Agamben's logic of the camp (Diken and Laustsen 2005). This site was neither only a practice of care, nor only a form of control of homeless people - but a machine that through its assemblages (diagrammatically activated through the suspension of the norm) deeply affected the subjects it encountered. 
Figure 3

The 'Emergenza Freddo' camp

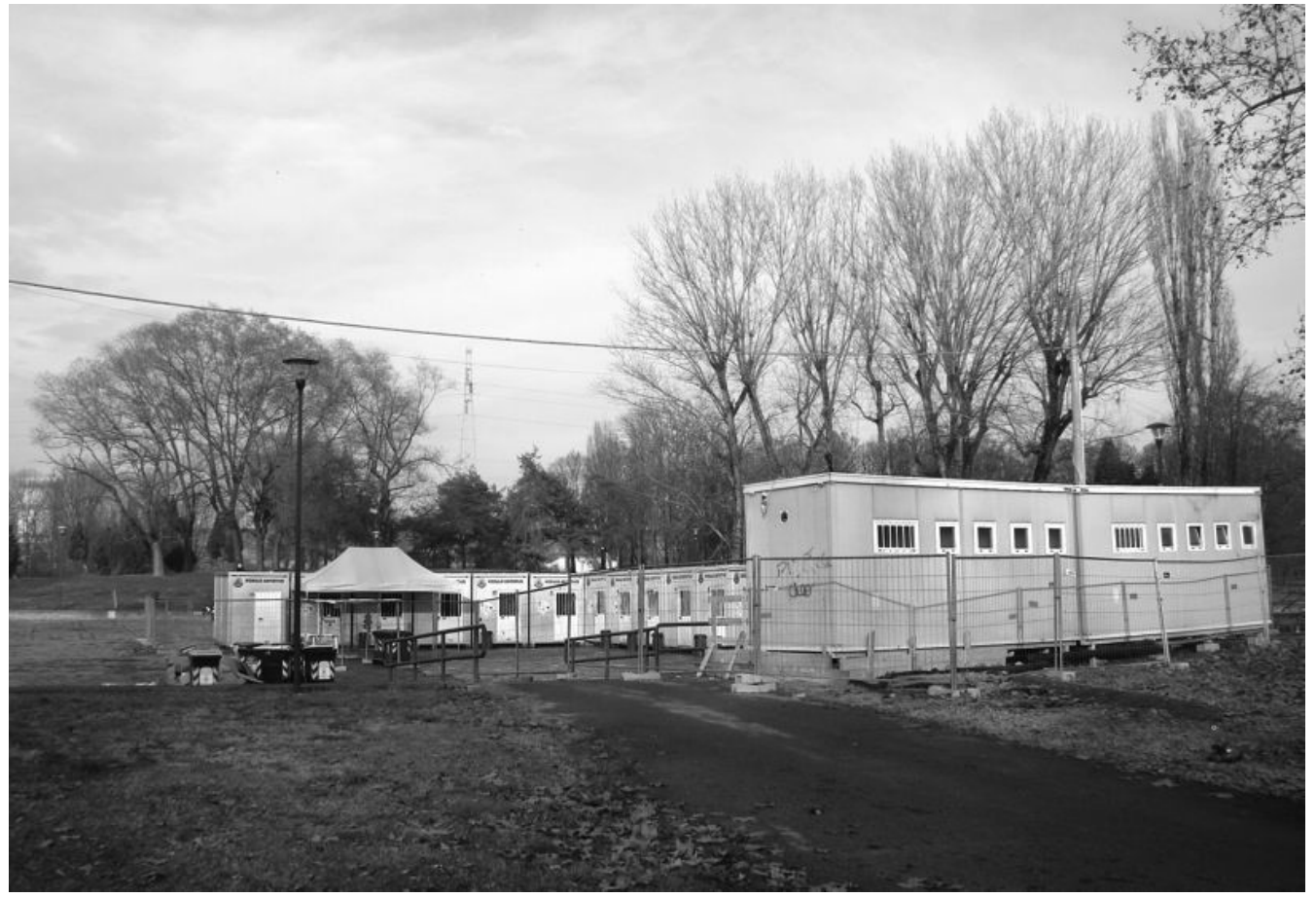

(Source: Lancione, 2010)

\section{A different assemblage of care}

Besides these normative policies, the City of Turin also provides services that seem to rely on a different kind of approach, one which pays greater attention to the heterogeneity of each subject. In what follows I am going to present one of them, called 'Educativa Territoriale', which will inform some of the reflections proposed at the end of the paper.

\section{The 'Educativa Territoriale'}

The 'Educativa Territoriale' was a group of three social educators based in a multi-functional centre located near the main train station of the 
city, in a street called 'via Sacchi', which also gave the informal name to this space. The 'via Sacchi' centre consisted of assemblages such as a shelter, a small medical clinic, and a space used for counselling. The discursive blueprint for the practices of care enacted in this space is clearly explained by what B.B. (the head educator of the centre) told me:

'We have to monitor the situation of homelessness on the streets of Turin, producing reports on it, and trying 'coupling' [get in touch] with the new homeless people that we encounter' (B.B., Apr. 2010).

Although the main aim of this service was to introduce homeless people to the world of public assistance, the Educativa Territoriale also offered another important service. The 'Educativa Territoriale"s project was designed to take into consideration the complexity of the urban homeless subject. B.B. was aware of the fact that homeless individuals are co-constituted with the city:

'The existence of a homeless people is sucked away by the street. The city is at the same time a resource, but also what changes you in your daily struggle to survive' (B.B., Apr. 2010).

B.B. and his team were approaching homeless individuals paying attention to their personal issues and street's histories, listening to them and spending time with them on the street, creating a good emphatic atmosphere that facilitated exchange and mutual respect. The approach of the 'Educativa Territoriale' was therefore aimed at taking into consideration the effects that the city had on homeless people (which were investigated and monitored), and at providing nonnormative, free to-use and loosely organised, services (like the showers, the teas, and the provision of basic medical care offered in the centre). Thanks to this approach B.B. was a widely known and respected figure among homeless people in Turin, and he really had a grasp of what was going on in train stations, meeting places and other hidden refuges. This knowledge, and the kind of work that he and his team were doing, were acknowledged and appreciated by homeless individuals themselves. Davide, a long-time street liver, liked the 'via Sacchi' 
centre not only because he could take a shower there and be visited by a doctor, but also because

'I like the way they treat me. You see, I can speak with B., I'm one of his friends. And I can go to the doctor too, all in the same place' (Davide, Mar. 2010).

The overall atmosphere of the centre can be described as positive and supportive (DeVerteuil and Wilton 2009). This was a context where people could come and go without feeling controlled, or pressured to achieve some specific, institutional ends. During the afternoon, when the medical clinic was open, homeless people were gathering around the place to chat, exchange information, or simply relax. They were having hot teas, taking showers and shavings without being bothered with too many questions by the social workers of the 'Educativa Territoriale', whom interacted with them in a friendly way without being paternalistic. The 'via Sacchi' centre was a fixed point on the map of many homeless individuals in the city. People like Valerio, a homeless individual with a history of behavioural problems, were going to the centre everyday at $4 \mathrm{pm}$, and staying there for at least a couple of hours chatting and enjoying a space that they perceived as 'OK' (Valerio, Mar. 2010).

Gathering in front of the centre, or stepping outside, was not perceived as detrimental - like it was in the case of the ' $1+1$ ' queue. People were not queuing, or waiting to receive a 'service': in front of the anonymous door of 'via Sacchi' (Figure 4) people were just hanging around, mixing with the pedestrians walking that same path, commenting on the cars passing by, or simply watching the flow of the city in front of them in a peaceful manner. Rules and codes of behaviour were implemented in the centre (for instance it was not possible to consume alcohol there). However, the attention to the needs of the individual and the friendly atmosphere of this space allowed B.B. and his team to avoid fights, or arguments, between their guests. The assemblage of care going on at the 'via Sacchi' centre was experienced, in other words, as a valuable resource and everyone was careful to avoid jeopardising it: they were 
perceiving it as a place to share, more than one to fight in. The diagram belonging to this assemblage-policy was one of allowing people to express, to exchange, to lead toward a positive (even if momentary) de-structuration, rather than one binding them to an unwanted (and stigmatising) territorialisation.

Figure 4

The entrance of the 'via Sacchi' multifunctional centre

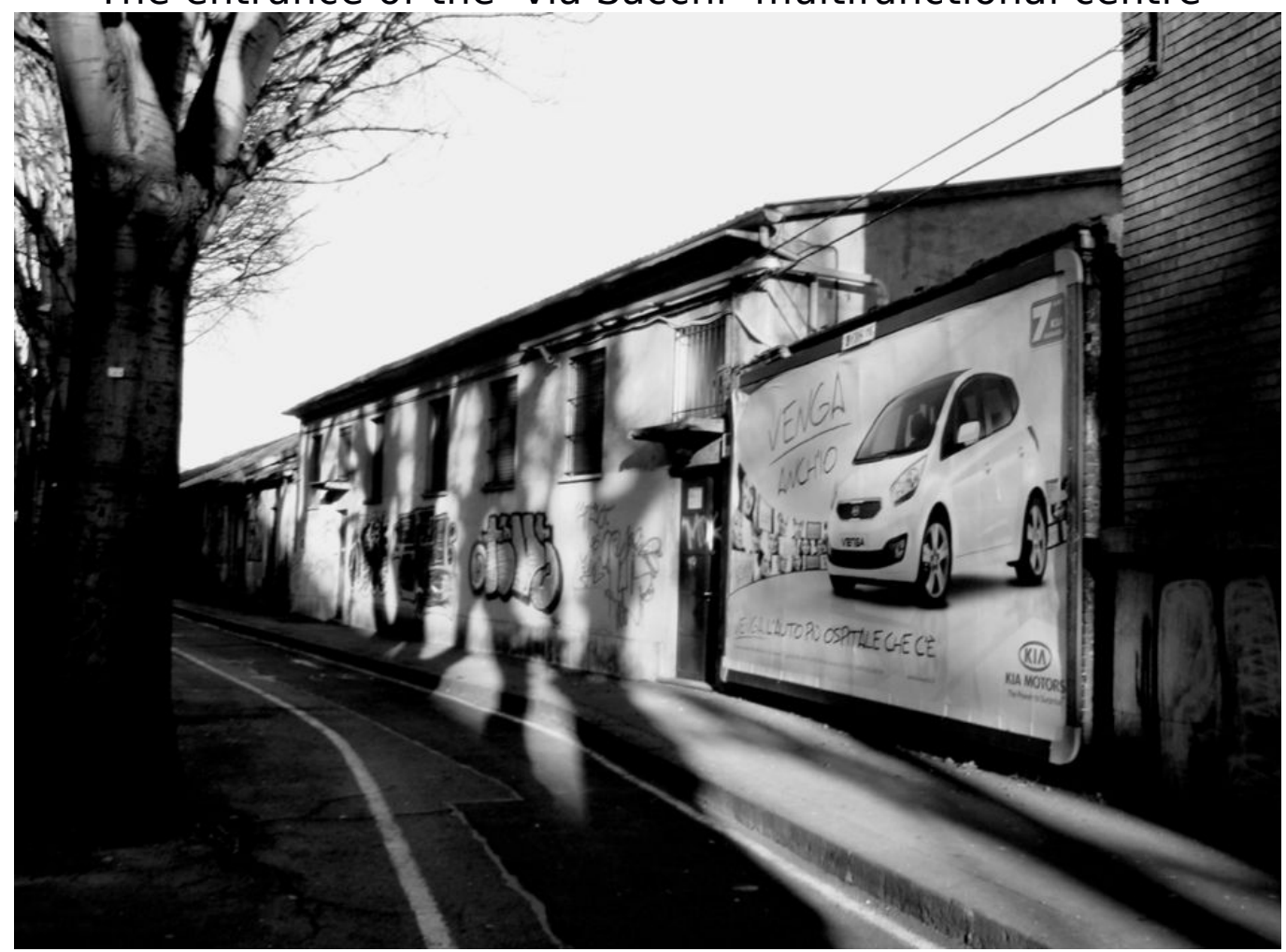

(Source: Lancione, 2010)

\section{Openings}

Refusing a-priori meta-explanations and categorisations, the assemblage-approach taken in the paper allows for a grounded, vitalist, and processual investigation into Turin's homeless policies. The aim has been to show how these assemblages of care contribute to the constitution of different experiences of homelessness, by mean of their discursive blueprint and practical enactments. Since the effects of these policies are mostly contingent, the question is then how may it be possible 
to control them, and how may we construct alternative arrangements (perhaps learning from the more positive endeavour shown in the previous section). In this sense, the paper concludes with three propositions that may also inform other contexts where similar interventions have been put in place.

First, attention should be given to the expression of these policies. For the most part they are not able to move away from certain fixed categories and a pre-determined understanding of homelessness, contributing to the constitution of highly stereotyped discourses on the matter - either from the sanitary, the material or the public security points of view. Without diminishing the importance of acknowledging issues of health, addiction, and lack of personal resources, a new discourse highlighting the capabilities, inventiveness, and resourcefulness of homeless people should be advanced. It is only by acknowledging these productive forces in meaningful ways that a new mode of thinking, imagining, and designing policy would eventually take place. The first step would hence be to 'restore an oppositional value system affirming that one can live a life of dignity and integrity in the midst of poverty' (hooks 1994, 170), not last through the public rejection of an exclusively normative understanding of homelessness. As Modood has argued, 'labels had to be contested and rejected through collective protest, the summoning and building up of group pride and the projection of positive labels and images to overcome the stigmatization of involuntary identities' (Modood 2007, 40). Academics have a relevant part to play here (Baeten 2004), also through nonacademic related activities. vi

Second, there is the necessity of a thoughtful investigation of the nonlinear, un-intentional, and diagrammatical effects of the content of these policies. Proposing redundant, undifferentiated and standardized services, these policies rigidly codify the street life of homeless people, without giving much space for other positive encounters. The ' $1+1$ ', as well as the 'Via della Casa Comunale, 1' residence, are cogent examples in this sense. Since these policies do not entail any degree of flexibility in relation to 
their audience, they can easily lead to the creation of repetitive sets of practices that have consequences both on the ways homeless people live their lives and on how they feel (as the example on Daniele and his old car shows). The work done by the 'Educativa Territoriale' could serve, in this sense, as a positive example to re-work the other interventions of the City, because it is carried first and foremost on the basis of the interpersonal relations of trust that B.B. and his team have with each homeless individual. The assemblages of care enacted by the 'Educativa Territoriale' are indeed oriented toward positive, flexible, and open relations to the subject that they encounter. In a sense, they assemble 'care' in a different way than the normative policies presented in the first half of the paper. Caring about each subjective experience on the street, and providing a safe and open environment for interaction, they allow for the free expression of the self (Parr 2000). Although the large-scale implementation of such practices definitely requires further investments in human resources, basic arrangements - like the re-imagination of the ' $1+1$ ' odd queuing system; or the insertion of flexible parameters in the evaluation of the fictive residence - could be provided at virtually no costs for the City.

Third, the articulation of these discourses and practices territorialise into assemblages that express particular affective power, which deeply influence homeless people's wellbeing (Robinson 2011). Assemblages like waiting lists, schedules, fictive ID cards, bunk beds, chairs, waiting rooms, etc. are the more-than-human means through which the encounters between homeless people and the City's interventions are framed (Amin 2012). In this sense, these actants need to be challenged and re-worked in order to change the kind of affective experience that they provide. The 'trans-human material culture' (Amin 2007, 110) enacted by the City's policies is then the arena that policy makers have to re-discover and rethink, even in those cases where local administrations are confronted with national cuts in the provided budget for public expenditure (something that seriously threatens the provision of those services). Most of the changes related to these assemblages can be very cost-effective. In the 
case of the 'Emergenza Freddo' camp, for instance, the number of bunk beds per container could be reduced in order to increase quality of the sleeping experience without affecting the overall service, since the camp never reaches its full capacity. Rules could be implemented more effectively, and basic facilities - like drawers or lockers to store personal belongings, which may foster a more intimate encounter with the place could be easily provided. Moreover, with a stronger political will: a) the camp could be re-located closer to the city centre; b) the containers could be replaced with more friendly prefabricated solutions (recycled wood is durable and affordable, and could offer an opportunity in this sense); c) and the 'camp' could also provide collateral interventions similar to those offered in the multifunctional centre of 'via Sacchi'.

Scholars, policy makers and practitioners face the challenge of imagining how different, non-normative, political paths could be implemented in order to dismiss the drawbacks of canonical policies of care for homeless people. Urban policy makers will need to pay attention to 'the ways in which their actions and reactions are responded to' (Darling 2011a, 415), but they will also need to confront the emotional consequences of the diagrammatical assemblages that they (mainly) unconsciously enact. Investigating the 'smell of the spike', and taking it seriously, is the best starting point for this endeavour.

\section{Acknowledgements}

The author wishes to thank the participants in the research, as well as Ash Amin, Francesca Governa, Stewart Clegg, and Leo for their support. Thanks also to Jonathan Darling, CITY's Editorial Board, and the two anonymous reviewers for the comments provided (the usual disclaimers apply). This paper is dedicated to Amos, Pancri, Paolo and Cardù.

\section{Notes}




\footnotetext{
i 'Spike' is the jargon used by Orwell to indicate a homeless shelter.

ii Note that these perspectives - the refusal of grand narrative and the explorative engagement with urban processes, which include also an attention to non-humans agencies - represent two of the three tenets characterising critical assemblage thinking according to McFarlane (2011a).

iii The distinction between 'expression' and 'content' is only analytical. In the process of assemblage they are articulated on the horizontal axis, with no prominence or causality of one toward the other, and on the vertical one - entangling in territorialisation, and disentangling in de-territorialisation (Deleuze and Guattari 1987; Dewsbury 2011).

iv A third possible case is of someone with a formal administrative residence in Turin (although obviously deprived of a physical accommodation). In this case the person is not managed by the SAD but by the general Social Service of the City.

${ }^{v}$ The names of the homeless people reported in the text have been modified to protect their privacy.

vi I played my part, in the Turin context, by 'translating' my research in a non-academic form: that of a novel. The book, called 'Il numero 1' (from 'Via della Casa Comunale, 1'; Lancione 2011b), was initially planned to be an auto-produced book to be distributed among the participants in the research. However it was eventually published and reached a wider audience. 'Il numero 1' features also 21 original illustrations done by a young Italian artist (Eleonora Mignoli), and a 'technical' appendix, which summarises the research findings and outlines possible changes in policy-making. The latter was read and well received by members of the City of Turin, and was then turned into an e-book freely available online:

'I finally read [...] 'Il numero 1. It is truly impressive how the book manages to captures the reality of the services offered by the City of Turin, and of homeless people, at least according to my experience. I hope to be able to use the Appendix in the reflections I will propose to my colleagues, both in City and in the cooperatives' (M.D., SAD operator, responsible for projects enacted in the 'via Sacchi' centre. Email, May 2012)
}

\section{References}

Agamben, G. 2005. State of Exception. Chicago: University of Chicago press.

Allen, J. 2011. 'Powerful Assemblages ?' Area 43 (2): 154-157.

Amin, A. 2007. 'Re-Thinking the Urban Social.' City 11 (1): 100-114.

Amin, A. 2012. Land of Strangers. Cambridge: Polity press.

Anderson, B. 2009. 'Affective Atmospheres.' Emotion, Society and Space 2 (2): $71-81$.

Anderson, B. 2012. 'Affect and Biopower: Towards a Politics of Life.' Transactions of the Institute of British Geographers 37 (1): 28-43.

Baeten, G. 2004. 'Inner-City Misery.' City 8 (2): 235-241.

Barnao, C. 2004. Sopravvivere in Strada. Elementi Di Sociologia Della Persona Senza Dimora. Work. Milano: Franco Angeli.

Basaglia, F. 1964. 'The Destruction of the Mental Hospital as a Place of Institutionalisation.' Presented at the First International Congress of Social Psychiatry, London. Available at http://www.triestesalutementale.it/english/doc/basaglia_1964_destruct ion-mhh.pdf 
Canguilhem, G. 1989. The Normal and the Pathological. New York: Zone books.

Città di Torino. 2009a. 'Nuovi Criteri Per La Presa in Carico Dei Cittadini Senza Dimora Con Residenza Fittizia in V. Della Casa Comunale Che Afferiscono Ai Servizi Sociali Circoscrizionali Ed Al Servizio Adulti in Difficoltà'. Turin.

Città di Torino. 2009b. 'Accesso Competenze e Servizi: Vademecum Per Gli Operatori Dei Servizi Sociali Territoriali'. Turin.

Città di Torino. 2009c. 'Bando Per II Finanziamento Del Progetto 'Interventi in Rete Per Fasce Di Popolazione a Rischio - Autunno Inverno 2009/2010". Turin.

Cloke, P., J. May, and S. Johnsen. 2008. 'Performativity and Affect in the Homeless City.' Environ. Plann. D 26 (2): 241-263.

Cloke, P., J. May, and S. Johnsen. 2010. Sweet up Lives? Re-Envisioning the Homeless City. Oxford: Blackwell Publishing.

Conradson, D. 2003a. 'Spaces of Care in the City: The Place of a Community Drop-in Centre.' Social \& Cultural Geography 4 (4): 507525.

Conradson, D. 2003b. 'Geographies of Care: Spaces, Practices, Experiences.' Social \& Cultural Geography 4 (4): 451-454.

Croce Rossa Italiana. 2008. 'Emergenza Freddo Stagione 2008-2009, Vademecum'. Turin.

Darling, J. 2011a. 'Giving Space: Care, Generosity and Belonging in a UK Asylum Drop-in Centre.' Geoforum 42 (4) (July): 408-417.

Darling, J. 2011b. 'Domopolitics, Governmentality and the Regulation of Asylum Accommodation.' Political Geography 30 (5): 263-271.

Davis, M. 1992. City of Quartz. New York: Vintage Books.

De Landa, M. 2000. 'Deleuze, Diagrams, and the Genesis of Form.' Amerikastudien / American Studies 45 (1): 33-41.

Deleuze, G. 1988. Foucault. Minneapolis: University of Minnesota Press.

Deleuze, G., and F. Guattari. 1987. A Thousand Plateaus. New York: Continuum.

Desjarlais, R. 1997. Shelter Blues: Sanity and Selfhood Among the Homeless. Philadelphia: University of Pennsylvania Press. 
DeVerteuil, G. 2003. 'Homeless Mobility, Institutional Settings, and the New Poverty Management.' Environment and Planning A 35 (2): 361379.

DeVerteuil, G. 2006. 'The Local State and Homeless Shelters: Beyond Revanchism?' Cities 23 (2): 109-120.

DeVerteuil, G. 2012. 'Does the Punitive Need the Supportive? A Sympathetic Critique of Current Grammars of Urban Injustice.' Antipode. doi:10.1111/anti.12001. http://doi.wiley.com/10.1111/anti.12001.

DeVerteuil, G., J. May, and J. von Mahs. 2009. 'Complexity Not Collapse: Recasting the Geographies of Homelessness in a 'Punitive' Age.' Progress in Human Geography 33 (5): 646-666.

DeVerteuil, G., and R. Wilton. 2009. 'Spaces of Abeyance, Care and Survival: The Addiction Treatment System as a Site of 'regulatory Richness'.' Political Geography 28 (8): 463-472.

Dewsbury, J-D. 2011. 'The Deleuze-Guattarian Assemblage: Plastic Habits.' Area 43 (2): 148-153.

Diken, B., and C. B. Laustsen. 2005. The Culture of Exception: Sociology Facing the Camp. London: Routledge.

Fallico, P. 2011. 'Torino, Viaggio Tra i 'senza Dimora'.' Nuova Societa'. Available at http://www.nuovasocieta.it/inchieste/torino-viaggio-tra-isenza-dimora.html.

Farías, I. 2011. 'The Politics of Urban Assemblages.' City 15 (3-4): 365-374.

Filipovi, M. H., E. Somogyi, and N. Teller. 2009. 'The Role of NGOs in the Governance of Homelessness in Hungary and Slovenia.' European Journal of Homelessness 3: 101-125.

Foucault, M. 1991. Discipline and Punish. The Brith of the Prison. London: Penguins.

Foucault, M. 2000. 'Governmentality.' In Power. Essential Works of Foucault, 1954-1984, Volume 3, edited by J. D. Faubion. London: Penguin.

Fyfe, N. R., and C. Milligan. 2003. 'Out of the Shadows: Exploring Contemporary Geographies of Voluntarism.' Progress in Human Geography 27 (4): 397-413.

Goffman, E. 1961. Asylums. Essays on the Social Situation of Mental Patients and Other Inmates. London: Anchor. 
Goffman, E. 1990. Stigma. Notes on the Management of Spoiled Identity. London: Penguin.

Gowan, T. 2000. ‘Excavating 'Globalization' from Street Level: Homeless Men Recycle Their Past'.' In Global Ethnography. Forces, Connections and Imaginations in a Postmodern World, edited by M. Burawoy. Los Angeles: University of California Press.

Gowan, T. 2010. Hobos, Hustlers and Back-Sliders: Homeless in San Francisco. Minneapolis: University of Minnesota Press.

Green, M., and V. Lawson. 2011. 'Recentring Care: Interrogating the Commodification of Care.' Social \& Cultural Geography 12 (6): 639654.

hooks, b. 1994. Outlaw Culture. New York: Routledge.

Huxley, M. 2007. 'Geographies of Governmentality.' In Space, Knowledge and Power. Foucault and Geography, edited by J. W. Crampton and S. Elden. Aldershot: Ashgate.

Johnsen, S., P. Cloke, and J. May. 2005a. 'Transitory Spaces of Care: Serving Homeless People on the Street.' Health \& Place 11 (4): 323-36.

Johnsen, S., P. Cloke, and J. May. 2005b. 'Day Centres for Homeless People: Spaces of Care or Fear?' Social \& Cultural Geography 6 (6): 787-811.

Lancione, M. 2011a. 'Homeless Subjects and the Chance of Space. A MoreThan-Human Geography of Homelessness in Turin (unpublished Ph.D. Thesis)'. Durham.

Lancione, M. 2011b. I/ Numero 1. Turin: Eris Edizioni.

Lancione, M. 2013a. 'Homeless People and the City of Abstract Machines. Assemblage Thinking and the Performative Approach to Homelessness.' Area 45 (3): 358-364.

Lancione, M. 2013b. 'How Is Homelessness?' The European Journal of Homelessness (FEANTSA) Forthcoming.

Lancione, M. 2014. 'Entanglements of Faith: Discourses, Practices of Care and Homeless People in an Italian City of Saints.' Urban Studies. Forthcoming.

Legg, Stephen. 2011. 'Assemblage / Apparatus: Using Deleuze and Foucault.' Area 43 (2): 128-133. 
Liebow, E. 1993. Tell Them Who Am I. The Lives of Homeless Women. New York: The Free Press.

May, J. 2000. 'Of Nomads and Vagrants: Single Homelessness and Narratives of Home as Place.' Environment and Planning D: Society and Space 18 (6): 737-759.

Mccann, E. (2011). Veritable inventions: cities, policies and assemblage. Area, 43(2), pp. 143-147.

McFarlane, C. 2011a. 'Assemblage and Critical Urban Praxis: Part One. Assemblage and Critical Urbanism.' City 15 (2): 204-224.

McFarlane, C. 2011b. 'On Context.' City 15 (3-4): 375-388.

Milligan, C., S. Atkinson, M. Skinner, and J. Wiles. 2007. 'Geographies of Care: A Commentary.' New Zealand Geographer 63 (2): 135-140.

Mitchell, D. 1997. 'The Annihilation of Space by Law: The Roots and Implications of Anti-Homeess Laws in the United States.' Antipode 29 (3): 303-335.

Mitchell, D., and N. Heynen. 2009. 'The Geography of Survival and the Right to the City: Speculations on Surveillance, Legal Innovation, and the Criminalization of Intervention.' Urban Geography 30 (6): 611-632.

Modood, T. 2007. Multiculturalism. A Civic Idea. Cambridge: Polity press.

Mol, A. 2008. The Logic of Care: Health and the Problem of Patient Choice. London: Routledge.

Parr, H. 2000. 'Interpreting the 'Hidden Social Geographies' of Mental Health: Ethnographies of Inclusion and Exclusion in Semi-Institutional Places.' Health \& Place 6 (3): 225-37.

Parr, H., and C. Philo. 1995. 'Mapping 'mad' Identities.' In Mapping the Subject. Geographies of Cultural Transformation, edited by S. Pile and N. Thrift. London: Routledge.

Romanillos, J.L., J. Beaumont, and M. Şen. 2013. 'State-Religion Relations and Welfare Regimes in Europe.' In Faith-Based Organisations and Exclusion in European Cities, 37-58. Bristol: Policy Press.

Ruddick, S. 2012. 'Power and the Problem of Composition.' Dialogues in Human Geography 2 (2): 207-211.

Smith, N. 1996. The New Urban Frontier: Gentrification and the Revanchist City. London: Routledge. 
Smith, N. 1998. 'Giuliani Time: The Revanchist 1990s.' Social Text 57: 120.

Snow, D. A, and L. Anderson. 1993. Down to Their Luck. A Study of Homeless Street People. Berkeley: University of California Press.

Staeheli, L. A., and M. Brown. 2003. 'Where Has Welfare Gone? Introductory Remarks on the Geographies of Care and Welfare.' Environment and Planning A 35 (5): 771-777.

Takahashi, L. M. 1996. 'A Decade of Understanding Homelessness in the USA: From Characterization to Representation.' Progress in Human Geography 20 (3): 291-310. 